\title{
Hepatitis B Among Pacific Islanders in Southern California: How is Health Information Associated with Screening and Vaccination?
}

\author{
Lois M. Takahashi • Anna J. Kim • Lola Sablan-Santos • \\ Lourdes Flores Quitugua · Jay Aromin · Jonathan Lepule • \\ Tony Maguadog $\cdot$ Rose Perez $\cdot$ Louise Young $\cdot$ Steve Young
}

Published online: 17 June 2010

(C) The Author(s) 2010. This article is published with open access at Springerlink.com

\begin{abstract}
We measured Hepatitis B virus (HBV) transmission knowledge and self-reported screening/testing behavior among Pacific Islanders (Guamanians/Chamorros, Samoans, and Tongans) in Southern California. We also examined access and trust by Pacific Islanders of varying health information sources. We administered and analyzed survey data $(N=297)$, using a convenience sample in Los Angeles, Orange, and San Diego Counties in spring 2009. We found that while Pacific Islander respondents reported that they receive health information from physicians, and largely trust this source, information from and trust in physicians were not statistically significant in explaining whether respondents sought HBV screening or vaccination.
\end{abstract}

L. M. Takahashi $(\bowtie)$

Departments of Urban Planning and Asian American Studies, UCLA, Box 951656, Los Angeles, CA 90095-1656, USA

e-mail: takahash@ucla.edu

A. J. Kim

Department of Urban Planning, UCLA,

Box 951656, Los Angeles, CA 90095-1656, USA

L. Sablan-Santos · L. F. Quitugua · J. Aromin

Guam Communications Network, 4201 Long Beach Blvd.,

Ste. 218, Long Beach, CA 90807, USA

J. Lepule

Pacific Islander Festival Association,

PO Box 86046, San Diego, CA 92138, USA

T. Maguadog $\cdot$ R. Perez

National Organization for the Advancement of Chamorro

People, PO Box 17203, Long Beach, CA 90807, USA

L. Young $\cdot$ S. Young

Kanana Fou Samoan Congregational Christian Church,

25304 Narbonne Avenue, Lomita, CA 90717, USA
Keywords Hepatitis B screening and vaccination Health information - Pacific Islander health .

Southern California

\section{Introduction}

Pacific Islanders in the US face a complex set of health challenges. This population, from a myriad of islands both US governed (e.g., the state of Hawai'i and US territories, including American Samoa, Guam, Commonwealth of the Northern Mariana Islands) and sovereign nations (e.g., Fiji, Federated States of Micronesia, Palau, Papua New Guinea, Samoa, Tonga), are often aggregated with Asian Americans, but are a distinct set of communities with different cultural norms, access to health, and health challenges.

Hepatitis B virus (HBV) infection, and the health problems associated with this (including but not limited to liver conditions such as cirrhosis and hepatocellular carcinoma) are highly prevalent among Asians/Pacific Islanders (APIs) in the US [1,2], and chronic HBV infection is endemic in the Pacific Islands [3]. However, most studies on API populations tend to focus more on Asians with less attention paid to Pacific Islanders, leading to an urgent need to examine the knowledge among US Pacific Islanders about Hepatitis B transmission and testing behavior.

In this paper we analyze the results of a recent community needs assessment survey of a convenience sample of Pacific Islanders in Southern California to investigate the associations among information sources, trust in sources, and selfreported HBV screening/testing and vaccination behavior. Though respondents largely reported that they were screened and vaccinated for HBV because of recommendations by their physicians, and that if they had not been screened and vaccinated for $\mathrm{HBV}$, they would seek screening vaccination 
on advice from their physicians, multivariate logistic regression analysis of the survey results suggest that obtaining information from and trust in physicians were not significant predictors of $\mathrm{HBV}$ screening or vaccination. Instead, for those respondents who sought screening/testing or vaccination for $\mathrm{HBV}$, significant factors included employment status and lack of knowledge about HBV.

To present these findings, the paper proceeds in the following manner. First, we describe the data and methods used, including a description of the convenience sample and a comparison of this sample to US Census data on the Pacific Islander population in Southern California. We then provide descriptive analysis of Pacific Islander respondents' knowledge about HBV transmission, questions about which sources of health information would lead respondents to be screened and vaccinated for $\mathrm{HBV}$, and trusted health information sources. Next, we present the results of multivariate logistic regression analysis of selfreported HBV screening and vaccination behavior. These results show that while respondents tend to report that physicians provide information and are highly trusted by these respondents as sources of information, information from and trust in physicians are not significant predictors of variations in self-reported HBV screening and vaccination. We conclude the paper with implications from this analysis for enhancing HBV screening and vaccination among Pacific Islanders in Southern California, and elsewhere.

\section{Methods}

A community needs assessment survey of Pacific Islander communities in the counties of Los Angeles, Orange, and San Diego in Southern California was conducted to measure Hepatitis B (HBV) knowledge, screening/testing, and vaccination, and trusted sources of health information.

\section{Questionnaires}

A survey questionnaire developed originally by the B Free CEED at the Center for the Study of Asian American Health, New York University School of Medicine (originally designed for surveys of Asian immigrants in New York City) was revised by several of the co-authors to be more culturally appropriate for Southern Californian Pacific Islanders. In November 2008, the Center for the Study of Asian American Health at NYU School of Medicine reviewed the adapted questionnaire, and made additional suggestions, including deleting several questions.

There were four English versions created of the survey questionnaire that targeted, respectively, Chamorro, Samoan, Tongan, and other Pacific Islander respondents. The English versions targeting Chamorro and Samoan respondents were translated into Chamorro and Samoan by several of the co-authors, and backtranslated into English. The two English versions (original and back-translated) were compared by one of the co-authors; minor revisions were made to the translated Chamorro and Samoan versions to improve clarity. The English and translated versions were pilot tested in late November 2008 with a total of 21 Chamorros, 1 Samoan, and 1 native Hawaiian; again, minor revisions were made to improve clarity.

The questionnaires were copied such that both the English and in-language versions were included in all questionnaires (English version on front and in-language version on back of each page). Respondents could therefore complete the questionnaire entirely in English, entirely inlanguage, or could move between the two depending on the respondent's preferences.

\section{Sampling Design}

A convenience sampling approach was used. Several of the co-authors distributed and collected the questionnaires from mid-February to mid April 2009 at community/ church meetings, cultural gatherings, and other community venues in Los Angeles, Orange, and San Diego counties. To minimize potential respondent bias, individuals were asked to complete the self-administered questionnaire and deposit the completed questionnaire in a sealed box. ${ }^{1}$ Each respondent was given a $\$ 5$ gift card as an incentive for completing the questionnaire.

The characteristics of the respondents overall and comparison to 2005-2007 Public Data Microdata Sample data $^{2}$ are listed in the Table 1. Compared to the PUMS sample, the convenience sample was more female, had lower annual household income, had larger household sizes, and was less often employed.

\section{Knowledge of Hepatitis B (HBV) and Reasons for Vaccination}

Respondents were asked questions about HBV transmission and ethnic group prevalence to assess their

\footnotetext{
1 As this was a community needs assessment survey conducted by community organizations, the survey and sampling were not reviewed by any IRB.

${ }^{2}$ Instead of the 2000 Census PUMS 5\% sample, the more current pooled data over the three years (2005-2007) of $1 \%$ samples of annual data were used for comparison. Samoan and Guamanian/ Chamorro self-identified individuals living in the metropolitan areas of Los Angeles-Long Beach, Orange County, and San Diego were aggregated $(N=616)$. The unweighted counts of both groups were compared to survey respondents based on similar demographic, economic, and household characteristics included in the PUMS sample.
} 
Table 1 Sample characteristics compared to 2005-2007 PUMS

\begin{tabular}{|c|c|c|}
\hline Demographic or health variable & $\begin{array}{l}\text { Respondent characteristics } \\
(N=297)\end{array}$ & $\begin{array}{l}\text { Comparison to } 2005-2007 \\
\text { PUMS }(N=616)\end{array}$ \\
\hline Ethnic background & $\begin{array}{l}51 \% \text { Samoan } \\
49 \% \text { Chamorro }\end{array}$ & $\begin{array}{l}53 \% \text { Samoan } \\
47 \% \text { Chamorro }\end{array}$ \\
\hline Gender & $\begin{array}{l}55 \% \text { female } \\
44 \% \text { male }\end{array}$ & $\begin{array}{l}49 \% \text { female } \\
51 \% \text { male }\end{array}$ \\
\hline Age & $\begin{array}{l}\text { Average }=40 \text { years } \\
\text { Range: } 16-82 \text { years }\end{array}$ & $\begin{array}{l}\text { Average }=38 \text { years } \\
\text { Range }=16-82 \text { years }\end{array}$ \\
\hline Place of birth & $\begin{array}{l}\text { 45\% California } \\
27 \% \text { Guam } \\
14 \% \text { American Samoa } \\
\text { 4\% Samoa/Western Samoa }\end{array}$ & $\begin{array}{l}46 \% \text { California } \\
18 \% \text { Guam } \\
10 \% \text { American Samoa } \\
8 \% \text { Western Samoa }\end{array}$ \\
\hline Number of years in US (for immigrants only) & $\begin{array}{l}\text { Mean }=29 \text { years } \\
\text { Range }=4-55 \text { years }\end{array}$ & $\begin{array}{l}\text { Mean }=28 \text { years } \\
\text { Range }=4-55 \text { years }\end{array}$ \\
\hline English language capacity & $\begin{array}{l}62 \% \text { speak English fluently } \\
24 \% \text { speak English very well }\end{array}$ & $\begin{array}{l}80 \% \text { speak English fluently } \\
8 \% \text { speak English well }\end{array}$ \\
\hline Pacific Islander language capacity & $\begin{array}{l}27 \% \text { speak Pacific Islander language fluently } \\
13 \% \text { speak very well } \\
11 \% \text { speak not at all }\end{array}$ & $\begin{array}{l}9 \% \text { speak Chamorro/Guamanian } \\
27 \% \text { speak Samoan } \\
45 \% \text { speak only English }\end{array}$ \\
\hline Marital status & $\begin{array}{l}43 \% \text { Married } \\
31 \% \text { Single or never married } \\
10 \% \text { Divorced or separated }\end{array}$ & $\begin{array}{l}51 \% \text { Married } \\
37 \% \text { Single or never married } \\
9 \% \text { Divorced or separated }\end{array}$ \\
\hline Health insurance & $17 \%$ No insurance & N/A \\
\hline Education & $\begin{array}{l}9 \% \text { Elementary school } \\
8 \% \text { Junior high school } \\
51 \% \text { High school or GED } \\
11 \% \text { Tech/vocational school } \\
19 \% \text { College or university graduate }\end{array}$ & $\begin{array}{l}15 \% \text { Elementary school } \\
4 \% \text { Junior high school } \\
28 \% \text { High school or GED } \\
20 \% \text { Some college } \\
10 \% \text { Junior college/college graduate }\end{array}$ \\
\hline Employment status & $\begin{array}{l}63 \% \text { Full/part time employed } \\
19 \% \text { Unemployed }\end{array}$ & $\begin{array}{l}89 \% \text { Full/part time employed } \\
11 \% \text { unemployed }\end{array}$ \\
\hline Household size & $\begin{array}{l}\text { Average: } 5.6 \\
\text { Range: } 1-40 \text { persons }\end{array}$ & $\begin{array}{l}\text { Average: } 4.9 \\
\text { Range: } 1-12\end{array}$ \\
\hline Household members younger than 18 & $\begin{array}{l}\text { Average: } 1.9 \\
\text { Range: } 0-13 \text { household members }<18 \text { years }\end{array}$ & $\begin{array}{l}\text { Average: } 0.85 \\
\text { Range: } 0-6 \text { own children present }\end{array}$ \\
\hline Household composition & 95\% Family & 99\% Family or sub-family \\
\hline Approximate total household income during last year & $\begin{array}{l}5 \% \text { Less than } \$ 10,000 \\
7 \% \$ 10,000-\$ 19,999 \\
17 \% \$ 20,000-\$ 29,999 \\
12 \% \$ 30,000-\$ 39,999 \\
7 \% \$ 40,000-\$ 49,999 \\
28 \% \$ 50,000 \text { or more } \\
24 \% \text { Not sure/Don't know }\end{array}$ & $\begin{array}{l}2 \% \text { Less than } \$ 10,000 \\
5 \% \$ 10,000-\$ 19,999 \\
9 \% \$ 20,000-\$ 29,999 \\
6 \% \$ 30,000-\$ 39,999 \\
8 \% \$ 40,00-\$ 49,999 \\
70 \% \$ 50,000 \text { or more }\end{array}$ \\
\hline
\end{tabular}

knowledge, about whether they had been advised or referred for HBV screening/testing and vaccination, and their self assessment of risk of HBV transmission (Table 2). A large proportion of respondents (63\%) reported that they had heard of $\mathrm{HBV}$, however, over half reported that they did not know which ethnic group(s) tends to most commonly have HBV. There also appears to be some confusion among respondents between HBV and Hepatitis A; $30 \%$ of respondents, for example, reported that HBV could be transmitted by eating unclean food, $26 \%$ reported that $\mathrm{HBV}$ could be transmitted via sharing food with an infected person and $21 \%$ reported that $\mathrm{HBV}$ could be transmitted via sharing utensils or chopsticks (these are transmission modes for Hepatitis A). 
Table 2 Knowledge of Hepatitis B virus transmission

\begin{tabular}{|c|c|}
\hline Knowledge variable & Response \\
\hline $\begin{array}{l}\text { Heard of } \\
\quad \text { Hepatitis B }(N=289)\end{array}$ & $\begin{array}{l}63 \% \text { yes } \\
23 \% \text { no } \\
14 \% \text { don't know }\end{array}$ \\
\hline $\begin{array}{l}\text { In your opinion, in which } \\
\text { ethnic group is Hepatitis } \\
\text { B most common? } \\
(N=283)\end{array}$ & $\begin{array}{l}3 \% \text { White } \\
8 \% \text { Black } \\
1 \% \text { Hispanic/Latino } \\
4 \% \text { Asian Americans } \\
\text { 4\% Pacific Islanders } \\
\text { 24\% All equally common } \\
56 \% \text { Don't know }\end{array}$ \\
\hline $\begin{array}{l}\text { In your opinion, Hepatitis B } \\
\text { can be transmitted by: } \\
(N=250 ; \text { more than } \\
\text { one answer possible })\end{array}$ & $\begin{array}{l}63 \% \text { unprotected sex } \\
63 \% \text { using contaminated needles } \\
61 \% \text { contact blood or bodily fluids } \\
\text { from an infected person } \\
38 \% \text { an infected mother to her } \\
\text { baby at the time of delivery } \\
30 \% \text { heredity } \\
30 \% \text { eating unclean food } \\
26 \% \text { sharing food with an infected } \\
\text { person } \\
21 \% \text { sharing utensils/chopsticks } \\
19 \% \text { kissing } \\
6 \% \text { other (le ilor, raw food, ti } \\
\text { utungo, toilet seat) }\end{array}$ \\
\hline
\end{tabular}

Between 61 and $63 \%$ of the respondents reported correctly that $\mathrm{HBV}$ could be transmitted via contact with blood or bodily fluids from an infected person, via unprotected sex, or via contaminated needles.

Of the total sample, $53(19 \%)$ reported that they had been screened for HBV, and $61(21 \%)$ reported that they had been vaccinated for HBV. These are much lower rates than reported in a recent study of Cambodian and Vietnamese Americans drawing from the Annual REACH 2010 Risk Factor Surveys [2].

Sizable proportions of respondents reported that they had not ever been told that they should be screened for HBV (40\%) or that they had never heard of HBV before participating in this community needs assessment survey (26\%). Of the one-third of total respondents who had been told that they should be screened for HBV, most had been advised to do so by a doctor and most of those respondents had been screened or tested for HBV (though about $16 \%$ of this group did not know or were unsure if they had been tested).

The $40 \%$ of the total respondents who reported that no one had suggested that they be screened for HBV indicated varying reasons for not being screened. The most common reasons were lack of knowledge, feeling well, not being suggested by a doctor, and not knowing where to get screened.
Table 3 Hepatitis B risk and most influence in screening/vaccination

\begin{tabular}{|c|c|}
\hline Awareness variable & Response \\
\hline $\begin{array}{l}\text { What influenced or would } \\
\text { influence you to get } \\
\text { Hepatitis B screening and } \\
\text { vaccination? }(N=252)^{\mathrm{a}}\end{array}$ & $\begin{array}{l}64 \% \text { Doctor told you to get screened } \\
35 \% \text { Family member is a carrier } \\
34 \% \text { Free screening/vaccination or if } \\
\text { covered by insurance } \\
32 \% \text { Fear of being infected by the virus } \\
31 \% \text { Encouraged by family members } \\
28 \% \text { Attended Hepatitis B educational } \\
\text { workshop } \\
22 \% \text { Encouraged by spouse } \\
21 \% \text { Encouraged by friends } \\
9 \% \text { Other (Bakura, Teacher, Employer, } \\
\text { Galuega, Travel) }\end{array}$ \\
\hline $\begin{array}{l}\text { Do you think you could be } \\
\text { infected with Hepatitis B? } \\
(N=280)\end{array}$ & $\begin{array}{l}6 \% \text { Yes } \\
52 \% \text { No } \\
41 \% \text { Not sure/Don't know }\end{array}$ \\
\hline $\begin{array}{l}\text { Have you ever been } \\
\text { diagnosed with Hepatitis } \\
\text { B infection? }(N=280)\end{array}$ & $\begin{array}{l}1 \% \text { Yes } \\
78 \% \text { No } \\
21 \% \text { Not sure/Don't know }\end{array}$ \\
\hline
\end{tabular}

a Total percentages may add up to more than $100 \%$ as respondents were asked to list all that apply; the only responses that were highly correlated (using Pearson correlation coefficient) were being encouraged by friends and family members

Similar patterns were exhibited concerning whether respondents were ever told that they should be vaccinated for HBV. About one-third of the respondents (36\%) reported that they had been told that they should obtain a vaccination for $\mathrm{HBV}$, while $39 \%$ reported that they had not ever been told to obtain a HBV vaccination, and $25 \%$ reported that they had never heard of HBV before participating in this community needs assessment survey. For the $36 \%$ of the respondents who had ever been told that they should obtain a HBV vaccination, almost all of the respondents $(87 \%)$ were told to do so by a doctor, and about two-thirds of those respondents reported that they had been vaccinated for HBV.

For the $39 \%$ of the respondents who reported not ever having been told to obtain an HBV vaccination, the most common reasons for not getting vaccinated included lack of knowledge and feeling well.

Over half of the respondents believed that they were not infected with $\mathrm{HBV}$, but $41 \%$ reported that they did not know (6\% believed that they might be infected) (Table 3). Over three quarters of the respondents reported that they had not ever been diagnosed with HBV, but $21 \%$ reported that they did not know or were not sure if they had ever been diagnosed with HBV. The most important influence appeared to be physicians' recommendations; almost twothirds of the respondents reported that if a doctor 
recommended that the respondent be screened, then this would influence that respondent to obtain HBV screening and vaccination.

\section{Physicians Appear to be Highly Trusted and Accessed Sources of Health Information}

Respondents were asked to indicate whether they had obtained information about health and health care from varied provider and community sources. The results are reported here by source, and then by utilization, and degree of trust depending on whether they had whether they had obtained information from specific sources (Table 4).

Respondents reported most often that they had obtained health and health care information from the following sources: physicians/health care providers (79\% reported that they had obtained information), pharmacists (53\% reported that they had obtained information), family members (48\% reported that they had obtained information), and community functions or health fairs (46\% reported that they had received information).

Respondents reported less often obtaining information from church, spiritual, or religious leaders $(31 \%$ reported obtaining information), friends (29\% reported obtaining information), employee assistance programs (26\% reported obtaining information), co-workers (20\% reported obtaining information), traditional healers $(17 \%$ reported obtaining information), and telephone advice lines (8\% reported obtaining information). Respondents who reported that they had obtained information from each of the sources also tended to report that they had used the source in the past year and trusted the information from that source. Not surprisingly, respondents who reported that they had not used each of the sources less often reported that they trusted information from that source.

Similar to the results reported in the earlier section on the descriptive statistics on HBV knowledge, screening/ testing, and vaccination, health care providers (including physicians and pharmacists) also appeared to be sources of information that these respondents would trust. In the following section, multivariate analyses are presented to ascertain socio-demographic or HBV knowledge association with trust in health information sources.

\section{Multivariate Logistic Regression: Factors Explaining HBV Screening and Vaccination}

Logistic regression models were estimated for the binary dependent variables measuring self-reported HBV screening/testing and vaccination behavior to ascertain how important sources of information, and trust in those sources, were when controlling for socio-demographic and health coverage characteristics, and HBV transmission knowledge. The dependent variables (whether respondents were screened for HBV and whether respondents were vaccinated for HBV) only included those respondents who had ever been told that they should be screened or vaccinated for HBV. In other words, those respondents who had never been told they should be screened or vaccinated for HBV (40\%) or who had never heard of HBV (26\%) prior to completing the survey were not included in this analysis. Though the resulting sample was smaller, it did provide the opportunity to assess the possible connections between screening/testing and vaccination self-reported behavior and other variables.

To construct the logistic regression models, chi-square tests were conducted of the dependent variables (respondent had been screened/tested for HBV, respondent had been vaccinated for HBV) using each set of variables (sociodemographic characteristics, health coverage, sources of health information, trust in health information sources, HBV transmission knowledge). Only those variables that were statistically significant at the $P<0.05$ level or better were retained for additional analysis. Pairwise Pearson correlation coefficients were calculated to ensure that the independent variables were not highly correlated. Using this variable screening process, the variables associated with physicians as sources of health information and trust associated with this health source were not retained (i.e., neither of these variables were significant at least at the $P<0.05$ level for either of the two dependent variables).

This suggested that while a very large proportion of respondents reported that they received health information from their physicians, and that they trusted this source, this had little explanatory power with respect to HBV screening/testing or vaccination for those respondents who had been informed that they should be screened or vaccinated for HBV. As the number of observations in each of the models was relatively small ( $N=63$ for the model for HBV screening/ testing, and $N=78$ for HBV vaccination), the results should be viewed as suggestive rather than conclusive.

Table 5 shows the results for a logistic regression model of HBV screening/testing for those respondents who had been informed that they should be screened for HBV. Two sets of variables were retained for the model after chisquare and Pearson correlation tests were conducted: sociodemographic and medical coverage characteristics, and information sources. Two variables were statistically significant at least at the $P<0.05$ level in explaining the variation in having been screened/tested for HBV: being currently employed and getting health and health care information from friends. The results indicated that fulltime employed respondents who have been informed that they should be screened/tested for HBV were over 6 times 
Table 4 Health information sources and trust (ranked by sources used by respondents)

\begin{tabular}{|c|c|c|}
\hline Information source & Reported getting information from this source & Reported NOT getting information from this source \\
\hline $\begin{array}{l}\text { Physician/health care provider } \\
\quad(N=275)\end{array}$ & $\begin{array}{l}79 \% \text { yes } \\
\text { For respondents who answered "yes" } \\
89 \% \text { used source in past year } \\
\quad 97 \% \text { trusted information from this source }\end{array}$ & $\begin{array}{l}21 \% \text { no } \\
\text { For respondents who answered "no" } \\
\quad 51 \% \text { trusted information from this source }\end{array}$ \\
\hline Pharmacists $(N=284)$ & $\begin{array}{l}53 \% \text { yes } \\
\text { For respondents who answered "yes" } \\
\quad 90 \% \text { used source in past year } \\
\quad 97 \% \text { trusted information from this source }\end{array}$ & $\begin{array}{l}47 \% \text { no } \\
\text { For respondents who answered "no" } \\
\quad 31 \% \text { trusted information from this source }\end{array}$ \\
\hline Family members $(N=280)$ & $\begin{array}{l}48 \% \text { yes } \\
\text { For respondents who answered "yes" } \\
\quad 89 \% \text { used source in past year } \\
83 \% \text { trusted information from this source }\end{array}$ & $\begin{array}{l}52 \% \text { no } \\
\text { For respondents who answered "no" } \\
25 \% \text { trusted information from this source }\end{array}$ \\
\hline $\begin{array}{l}\text { Community functions or health } \\
\text { fairs }(N=287)\end{array}$ & $\begin{array}{l}46 \% \text { yes } \\
\text { For respondents who answered "yes" } \\
\quad 84 \% \text { used source in past year } \\
92 \% \text { trusted information from this source }\end{array}$ & $\begin{array}{l}54 \% \text { no } \\
\text { For respondents who answered "no" } \\
\quad 24 \% \text { trusted information from this source }\end{array}$ \\
\hline $\begin{array}{l}\text { Church, spiritual or religious } \\
\text { leaders }(N=289)\end{array}$ & $\begin{array}{l}31 \% \text { yes } \\
\text { For respondents who answered "yes" } \\
\quad 83 \% \text { used source in past year } \\
\quad 94 \% \text { trusted information from this source }\end{array}$ & $\begin{array}{l}69 \% \text { no } \\
\text { For respondents who answered "no" } \\
\quad 18 \% \text { trusted information from this source }\end{array}$ \\
\hline Friends $(N=292)$ & $\begin{array}{l}29 \% \text { yes } \\
\text { For respondents who answered "yes" } \\
\quad 87 \% \text { used source in past year } \\
\quad 91 \% \text { trusted information from this source }\end{array}$ & $\begin{array}{l}71 \% \text { no } \\
\text { For respondents who answered "no" } \\
\quad 13 \% \text { trusted information from this source }\end{array}$ \\
\hline $\begin{array}{l}\text { Employee assistance programs } \\
\qquad(N=288)\end{array}$ & $\begin{array}{l}26 \% \text { yes } \\
\text { For respondents who answered "yes" } \\
\quad 90 \% \text { used source in past year } \\
\quad 97 \% \text { trusted information from this source }\end{array}$ & $\begin{array}{l}74 \% \text { no } \\
\text { For respondents who answered "no" } \\
\quad 18 \% \text { trusted information from this source }\end{array}$ \\
\hline Co-workers $(N=290)$ & $\begin{array}{l}20 \% \text { yes } \\
\text { For respondents who answered "yes" } \\
\quad 77 \% \text { used source in past year } \\
\quad 84 \% \text { trusted information from this source }\end{array}$ & $\begin{array}{l}80 \% \text { no } \\
\text { For respondents who answered "no" } \\
\quad 14 \% \text { trusted information from this source }\end{array}$ \\
\hline Traditional healers $(N=283)$ & $\begin{array}{l}\text { 17\% yes } \\
\text { For respondents who answered "yes" } \\
\quad 69 \% \text { used source in past year } \\
85 \% \text { trusted information from this source }\end{array}$ & $\begin{array}{l}83 \% \text { no } \\
\text { For respondents who answered "no" } \\
\quad 16 \% \text { trusted information from this source }\end{array}$ \\
\hline Telephone advice lines $(N=288)$ & $\begin{array}{l}8 \% \text { yes } \\
\text { For respondents who answered "yes" } \\
\quad 71 \% \text { used source in past year } \\
\quad 96 \% \text { trusted information from this source }\end{array}$ & $\begin{array}{l}92 \% \text { no } \\
\text { For respondents who answered "no" } \\
\quad 13 \% \text { trusted information from this source }\end{array}$ \\
\hline
\end{tabular}

more likely to have been screened or tested for $\mathrm{HBV}$ compared to respondents who had been informed that they should be screened/tested for HBV but who did not report being full time workers (e.g., part time workers, retired, unemployed). In terms of health information sources, respondents who reported that they received health and health care information from their friends and who had been informed that they should be screened/tested for HBV were over 7 times more likely to also report that they had been screened or tested for HBV compared to respondents who had been informed that they should be screened/tested for HBV, but who did not report that they had received information about health or health care from their friends.

Table 6 shows the results of the multivariate logistic regression model for the dependent variable measuring self-reports of vaccination for HBV (only including those 
Table 5 Logistic regression results for Hepatitis B screening/testing $(N=63)$

\begin{tabular}{|c|c|c|c|c|c|}
\hline $\begin{array}{l}\text { Variable (bolded variables are statistically significant at } \\
\text { least at } P<0.05 \text { ) }\end{array}$ & $\begin{array}{l}\text { Odds } \\
\text { ratio }\end{array}$ & SE & $Z$ & $P>|\mathrm{Z}|$ & $\begin{array}{l}95 \% \text { confidence } \\
\text { interval }\end{array}$ \\
\hline \multicolumn{6}{|l|}{ Demographics/medical coverage } \\
\hline Has medicare coverage $(1=$ yes, $0=$ no $)$ & 0.32 & 0.29 & -1.27 & 0.20 & $0.06-1.86$ \\
\hline $\begin{array}{l}\text { Highest grade of school completed }(1=\text { elementary school, } \\
6=\text { post-graduate school })\end{array}$ & 1.59 & 0.53 & 1.39 & 0.16 & $0.83-3.07$ \\
\hline Currently employed full time $(1=$ yes, $0=$ no $)$ & 6.35 & 5.93 & 1.98 & 0.05 & $1.02-39.60$ \\
\hline Currently retired $(1=$ yes, $0=$ no $)$ & 7.42 & 10.19 & 1.46 & 0.15 & $0.50-109.47$ \\
\hline \multicolumn{6}{|l|}{ Information sources } \\
\hline $\begin{array}{l}\text { Gets information about health and health care from } \\
\text { friends }(1=\text { yes, } 0=\text { no) }\end{array}$ & 7.67 & 7.98 & 1.96 & $\mathbf{0 . 0 5}$ & $\mathbf{1 . 0 0 - 5 8 . 9 2}$ \\
\hline $\begin{array}{l}\text { Gets information about health and health care from the } \\
\text { Internet }(1=\text { yes, } 0=\text { no })\end{array}$ & 1.75 & 1.63 & 0.59 & 0.55 & $0.28-10.94$ \\
\hline $\begin{array}{l}\text { Gets information about health and health care from Pacific } \\
\text { Islander organizations }(1=\text { yes, } 0=\text { no })\end{array}$ & 4.06 & 3.87 & 1.47 & 0.14 & $0.63-26.24$ \\
\hline \multicolumn{6}{|l|}{ Model goodness of fit measures } \\
\hline $\operatorname{LR} \operatorname{chi} 2(d f=7)$ & & & & & \\
\hline Prob $>$ chi 2 & & & & & \\
\hline Pseudo $R 2$ & & & & & \\
\hline Log likelihood & & & & & \\
\hline
\end{tabular}

respondents who reported that they had been informed that they should be vaccinated). The only demographic or medical coverage variable that was a significant predictor of whether respondents reported that they had been vaccinated for HBV was whether the respondent reported being covered by Medicare; those who reported being covered by Medicare were 0.02 times as likely as respondents who did not report that they were covered by Medicare to also report that they had been vaccinated for $\mathrm{HBV}^{3}$

There is one HBV transmission knowledge question that was significant at least at the $P<0.05$ level; responding that Hepatitis B could be transmitted by eating unclean food (an incorrect response) was associated with also reporting being vaccinated for HBV. In other words, contrary to most interventions that might presume that more and better knowledge leads to protective and health promoting behavior, this result suggested that not understanding how HBV is transmitted (i.e., confusing HBV with Hepatitis A) was related to higher likelihood of being vaccinated for HBV. Those who answered this question incorrectly were over 8 times more likely to report that they had been vaccinated for HBV compared to respondents who answered this question correctly.

\footnotetext{
3 This might first appear that age is related to vaccination behavior, but age was not statistically significant using an ANOVA test at the $P<0.05$ level.
}

Similar to the model presented previously on selfreported HBV screening/testing behavior, being employed again appeared to be important in explaining the variation in self-reported vaccination for HBV, however, in this model, employment had a negative association. Obtaining information about health and health care from employee assistance programs was negatively associated with HBV vaccination for those respondents who had been informed that they should be vaccinated for HBV.

\section{Summary and Implications}

In this paper, results were presented of an analysis of a recent community needs assessment survey of a convenience sample of Pacific Islanders in Southern California. Because this was a convenience sample and, in addition, because the multivariate analysis used a small subsample of the total sample, the results must be viewed as suggestive rather than conclusive.

The findings indicated that though Pacific Islander respondents reported that physicians and pharmacists, i.e., health care providers, were the most trustworthy and commonly used source of health care information and advice, when multivariate analysis was conducted to explain the variation in self-reported HBV screening/testing and vaccination behavior, trust in and use of physicians for health care information was not statistically significant. 
Table 6 Logistic regression results for Hepatitis B vaccination $(N=78)$

\begin{tabular}{|c|c|c|c|c|c|}
\hline $\begin{array}{l}\text { Variable (bolded variables are statistically significant at } \\
\text { least at } P<0.05 \text { ) }\end{array}$ & $\begin{array}{l}\text { Odds } \\
\text { ratio }\end{array}$ & SE & $Z$ & $P>|\mathrm{Z}|$ & $\begin{array}{l}95 \% \text { confidence } \\
\text { interval }\end{array}$ \\
\hline \multicolumn{6}{|l|}{ Demographics/medical coverage } \\
\hline Has medicare coverage $(1=$ yes, $0=$ no $)$ & 0.02 & 0.02 & -3.24 & 0.001 & $0.00-0.21$ \\
\hline $\begin{array}{l}\text { Highest grade of school completed }(1=\text { elementary school, } \\
6=\text { post-graduate school })\end{array}$ & 1.04 & 0.30 & 0.13 & 0.90 & $0.59-1.81$ \\
\hline $\begin{array}{l}\text { Currently employed part time (one part time position) } \\
(1=\text { yes, } 0=\text { no })\end{array}$ & 0.29 & 0.25 & -1.41 & 0.16 & $0.05-1.62$ \\
\hline Currently retired $(1=$ yes, $0=$ no $)$ & 4.04 & 5.46 & 1.03 & 0.30 & $0.29-57.03$ \\
\hline \multicolumn{6}{|l|}{ Hepatitis B knowledge } \\
\hline $\begin{array}{l}\text { In your opinion, Hepatitis } B \text { can be transmitted by } \\
\text { eating unclean food }(1=\text { true, } 0=\text { false })\end{array}$ & 8.34 & 7.66 & 2.31 & 0.02 & $1.38-50.46$ \\
\hline \multicolumn{6}{|l|}{ Information sources } \\
\hline $\begin{array}{l}\text { Gets information about health and health care from the } \\
\text { employee assistance program }(1=\text { yes, } 0=\text { no })\end{array}$ & 0.12 & 0.09 & -2.76 & 0.01 & $0.03-0.54$ \\
\hline $\begin{array}{l}\text { Gets information about health and health care from social } \\
\text { service provider or community health center }(1=\text { yes, } \\
0=\text { no) }\end{array}$ & 0.71 & 0.53 & -0.46 & 0.64 & $0.17-3.03$ \\
\hline \multicolumn{6}{|l|}{ Model goodness of fit measures } \\
\hline LR $\operatorname{chi} 2(d f=7)$ & & & & & \\
\hline Prob $>$ chi 2 & & & & & \\
\hline Pseudo $R 2$ & & & & & \\
\hline Log likelihood & & & & & \\
\hline
\end{tabular}

Instead, the factors that were important in explaining HBV screening/testing for respondents who had been told that they should be screened or tested for HBV included being currently employed and receiving health and health care information from friends. Being employed and receiving health and health care information from friends were both associated with much higher likelihoods of being screened or tested for HBV, compared to respondents who were not currently employed or who did not receive health information from friends. The factors that were important in explaining self-reported HBV vaccination behavior were different from those explaining the variation in HBV screening/testing. Not being covered by Medicare, having incorrect knowledge about HBV transmission (confusing HBV with Hepatitis A), and not receiving information from employee assistance programs were associated with selfreported HBV vaccination. These results were somewhat counterintuitive, as more and correct information is usually presumed to result in enhanced screening and health care access.

These findings suggested that though these respondents viewed physicians and pharmacists positively, and a large proportion reported that they obtained health care information from health care providers, that other factors (demographic, knowledge, and information source) were more important in explaining HBV screening and vaccination behavior. One possible interpretation of these findings is that health recommendations for HBV screening and vaccination may need to come from physicians, who are highly trusted sources, but that additional motivations (information from friends) or opportunities for access to health care (being full time employed, presumably with health care benefits) may also be necessary to expand the number of Pacific Islanders who are screened and vaccinated for Hepatitis B. Additional research is needed to ascertain whether these findings hold for other Pacific Islander groups in California, nationally, and on the island jurisdictions.

Acknowledgments Funding was provided through a Legacy pilot grant from the B Free CEED: National Center of Excellence in the Elimination of Hepatitis B Disparities of the Institute of Community Health and Research at NYU Langone Medical Center. B Free CEED is supported by Grant Number DP07-707, Racial and Ethnic Approaches to Community Health Across the US from the Centers for Disease Control and Prevention. Special thanks to Dr. Simona Kwon of NYU School of Medicine, and the community members that participated in this project. We take full responsibility for all errors and omissions.

Open Access This article is distributed under the terms of the Creative Commons Attribution Noncommercial License which permits any noncommercial use, distribution, and reproduction in any medium, provided the original author(s) and source are credited. 


\section{References}

1. Hu, K.-Q. (2008). Hepatitis B virus (HBV) infection in Asian and Pacific Islander Americans (APIAs): How can we do better for this special population? American Journal of Gastroenterology, 103, 1824-1833.

2. Grytdal, S. P., Liao, Y., Chen, R., Garvin, C. C., Grigg-Saito, D., Kagawa-Singer, M., et al. (2009). Hepatitis B testing and vaccination among vietnamese and Cambodian-Americans. Journal of Community Health, 34, 173-180.

3. Custer, B., Sullivan, S. D., Hazlet, T. K., Iloeje, U., Veenstra, D. L., \& Kowdley, K. V. (2004). Global epidemiology of Hepatitis B virus. Journal of Clinical Gastroenterology, 38(10 Suppl), S158S168. 